\title{
Beware of the Dogs: The Position and Role of Dogs in Biblical Discourse
}

\author{
Daniel Berkovic \\ Biblical institute, Zagreb, Croatia
}

Email address:

danijel.berkovic1@inet.hr

To cite this article:

Daniel Berkovic. Beware of the Dogs: The Position and Role of Dogs in Biblical Discourse. International Journal of Literature and Arts. Vol. 3, No. 1, 2015, pp. 7-11. doi: 10.11648/j.ijla.20150301.12

\begin{abstract}
Animals and humanbeings are closely connected,whether this be in harmony or conflict. Animals may be our friends and helpers, but also may become our food. The history of religions, shows us that animal can become a centre of religious worship (zoolatry) or/and a sacrificial offering. The latter becomes themeans of mediation between the human and the divine realm. In biblical discourse, the relationship between people and animalsis depictedeither in terms of human superiority over the animal world, "so that they may rule over the fish in the sea and the birds in the sky, over the livestock and all the wild animals, and over all the creatures that move along the ground" (Gen 1:26-30) or as a relationship of mutual fear, "The fear and dread of you will fall on all the beasts of the earth, and on all the birds in the sky, on every creature that moves along the ground, and on all the fish in the sea; they are given into your hands". (Gen 9:2). Finally, in biblical discourse, animals are food for humans, "Everything that lives and moves about will be food for you. Just as I gave you the green plants, I now give you everything". (Gen 9:3). Examining biblical bestiary, we shall particularly be interested in relation to the position of dogs in the Bible.
\end{abstract}

Keywords: Animals, Livestock, Dog, Zoonymy, Anthroponym, Bestiary,Zoolatry, Spirit, Guide

\section{The Biblical Bestiary}

The biblical bestiary is more a zoo than a farm. Dogs in the biblical text are neither domestic animals nor pets. They are stuckhalfway between wild animals and those useful to man. However, dogs are used in a specific metaphorical sense, and in the religious-historic context, are an unavoidable, crucial species. ${ }^{1}$

Sheep and goats prevail among domestic animals in biblical animal husbandry. The dog as we know it has no place in that context. Despite the fact that sheep farming was well developed in ancient Israel, mainly for religious reasons, sheepdogs are only mentioned once. In his lamentation, Job reflects on those who mock him in his despair, and sayshe would not entrust their fathersto his sheepdogs:

'But now they mock me, men younger than I, whose fathers I would have disdained to put with my sheepdogs.'(כלבי צאני) (Job 30:1).

1 In his detailed study of biblical taxonomyWhitekettle mentions dogs (Whitekettle, 2001).
In terms of livestock, the Hebrew noun tson(צאן) is a generic term for small domestic animals. Often, sheep and cattle baqar (בקר) are mentioned together when livestock is listed. Goats $a z$ (ע) are mentioned too. Jacob was said to own "two hundred female goats (עים) and twenty male goats (תישים), two hundred ewes and twenty rams," (Gen 32:14). Lot had 'sheep and cattle' (צאן־ובקר) (Genesis 13:5), it was said he owned sheep and cattle 'abundantly' (הרבק מאד). Abraham's list of possessions was even longer. He also owned 'donkeys and camels' (אתנת (Gen 12:16. ${ }^{2}$ King's Solomon's table included game (venison, gazelles and roebucks; cf.1Kings 4:23). However, there are no poultry in a typical biblical homestead, nor pigs, of course, and there are no horses either. Pets are not even mentioned.

All other creatures are in fact categorised as wild animals. But in the biblical bestiary, one animal holds a special place, though it is not a place of honour - the dog. It cannot be said to be a wild beast, but neither is it a tame, domesticated animal. According to all biblical reports, dogs roam in packs. In some biblical scenes, they are described as scavengers.

Apostle Paul's warning in the New Testament: "Watch out

אתן2 גמול (donkey); (camel) 
for those dogs" (Phil 3:2,"Beware of dogs" KJV) is not a sign taken from a wall or average biblical Jewish front gate. These animals in the biblical days, were no guarddogs. In fact, following biblical texts and context, would it not have been more appropriate to say: "Beware of lions" or "Look out for snakes"? You would not have seen a picture of a dog in a typical Jewish courtyard with the message, "Fierce dog", or "They may not be home, but I am..." or the likes.

The apostle issues a severe, sarcastic warningin his letter to the Philippian Christian community. He attacks verbally a group of malicious enemies, calling them: 'evildoers' (tou.$j$ kakou.j evrga, taj) and 'dogs' (ku, naj) (Phil 3:2; cf. Bockmuehl, 1997:182-186). Evidently, dogs were a real and present danger, which is why Paul decided to use them as a metaphor (see Peterlin 1995:96-97). But this kind of warning, and the role of dogs in the biblical context, have a specific, metaphoric meaning. We also need to remember the role of the animal within the religious-historic and mythical contexts and how this fits in the biblical context.

Obviously, Paul uses the image of dogs and how they were treated from the perspective of the Old Testament and early Judaism. He mentions dogs here in the plural, in a pack, which ishow they are usually encountered in the literary context of the Old Testament.

\section{Man's Best Friend}

Dogs come in many kinds, and quite possibly in the largest number of breeds. There are large, enormous dogs, but also pocket-sized specimens. Some are trained to guard homes, property, or flocks of sheep. There are also rescue dogs, and dogs trained to find dangerous substances. Some are simply companions for their human owners, enjoying anything but a 'dog's life'. Among modern pets, there is a great variety of dogs. It is interesting that the Croatian word for 'breed' is 'pasmina' which actually contains the word for 'dog' - 'pas'.

Dogs as 'man's best friend' are quite a modern novelty. There are historical traces proving that dogs were domesticated before the emergence of early Israel (see McCullough, IDB vol. 1:862). One rare, rather mysterious reference to a dog isfound in a story of Tobit, who sends his son Tobias on a journey to the land of Media to regain his father's ten silvercoins. Tobias is accompanied by Raphael, and a dog. Tobit bids farewell to his son and says,

Prepare what you need for the journey, and set off with your brother. May God in heaven protect you abroad and bring you both back to me safe and sound! May his angel go with you and protect you.' The boy left with the angel, and the dog followed behind (Tobit 5:17-6:1)

After a while, Tobias begins to worry about his sick father, so Raphael tells him,

You know the plight in which we left your father; let us go on ahead of your wife and prepare the house ourselves while she travels behind with the others.' They went on together (Raphael warned Tobias to take the gall with him) and the dog followed them (Tobit 11:3-4)

In other biblical texts, dogs are considered worthless animals. In a cynicalevaluation of life in general, the preacher in Ecclesiastes concludes,

Surely the fate of human beings is like that of the animals; the same fate awaits them both: As one dies, so dies the other. All have the same breath; humans have no advantage over animals. Everything is meaningless (Eccl $3: 19)$

The same biblical writer pragmatically concludes, "Even a living dog is better off than a dead lion!” (Eccl 9:4).

\section{Dogs as Metaphors}

As with other animals, there is a whole spectrum of zoonymic phrases which bring dogs into the human world, as symbolsof,or descriptions for,human characteristics or conditions. The hottest time of the year is known as the 'dog days'. When life is hard, we call it a 'dog's life'. You might be as 'tired as a dog'. A complete mess is described as a 'dog's breakfast'. People are sometimes accused of sounding like dogs - a sergeant-major 'barks' orders, while comedians make audiences 'howl' with laughter. Animal noises are often onomatopoeic. A cuckoo calls its name. A cat meows. This is how the biblical writer describes the enemies of the psalmist and of God,

Consume them in your wrath,consume them till they are no more.Then it will be known to the ends of the earththat God rules over Jacob.They return at evening,snarling like dogs (יהמו ככלב), and prowl about the city. (Ps 13-14)

In terms of anthroponyms, dogs arerather discriminated against, unlike their relative the wolf. Many surnames in both Croatian and English reflect this (Vuk, Vuković, Vučinić, Vučković, Wolfson, Wolfner, Wolfman, etc.). Actually, there is awhole zoo of Croatian surnames,but there is hardly any mention of dogs.

\section{From Wolf to Pet}

Perhaps it would be better to say 'from scavenger to pet'. The modern domesticdog bears little resemblance to those found in the biblical text and context. Among all the animals, apart from the pig, the dog is given a very low rank, lower even than carrion eaters.

The dog of the Bible was a sort of wandering wolf (see Skok, 1972:II:243), which was only domesticated much later. The wolf is a symbol and synonym for a killer, a wanderer, and a warrior. It rules the winter snows, when it joins with others to form a threatening, predatory group, common in folk stories. The wolf in thestory of Little Red Riding Hoodis cunning and shrewd, a voracious enemy who attacks and devours (cf. Gen 49:27; Jer 5:6). ${ }^{3}$ Finally, the wolf is

3 See Botterweck, 1980 
transformed into the mythical werewolf,signifying the dark forces of evil. ${ }^{4}$ Interestingly, the Bible does not describe the wolf (זאב) as an unclean animal though the dog (כלב) is. The wolf is described as dangerous, predatory foe (Jer 5:6, Zeph $3: 3$, whose natural instincts must be tamed in theidyllic contextof reign of peace and coexistence,

"The wolf and the lamb will feed together, and the lion will eat straw like the ox, and dust will be the serpent's food. They will neither harm nor destroy in all my holy kingdom."' (cf. Is 11:6, 65:26).

The dog has no part in this scene.Along with the pig, the most ritually unclean animal, the dog is a scavenger who feeds on carrion. By the time of the New Testament, even if it lives alongside people, it is only fed the scraps (cf. Mt 15:26) It will even eat human corpses (cf. $1 \mathrm{Ki} \mathrm{14:11),} \mathrm{as} \mathrm{well} \mathrm{as} \mathrm{its}$ own vomit (Prov 26:11, 2 Pt 2:22). Also, the dysphemism 'dead $d o g$ 'is a terrible insult and a description of extreme humiliation;as in 2 Sam 16:9. In the story, Shimei from the Saulite descent, cursed king David and threw stones at him. There then certain Abishai in defence of his master, king David spoke and said:

"Why should this dead dog (הכלב המת) curse my lord the king? Let me go over and take off his head" (16:9).

On the other hand, it may also serve as a sign of outmost humility as in the story of Meribaal (the son of Jonathan, son of Saul) who, perhaps even in fear for his life, spoke to king David and said:

What is your servant, that you should notice a dead dog like me? (2 Sam 9:8)

For the Israelitesit was not allowed to consume meat which had been torn apart by animals, particularly dogs. In fact, such meat was only worthy to be thrown to the dogs:

You are to be my holy people. So do not eat the meat of an animal torn by wild beasts; throw it to the dogs (Exodus 22:31).

\section{Religious and Biblical Bestiaries}

The worship of animals, assigning them divine properties (zoolatry) is a well known element in the history of religion. ${ }^{5}$ The animal symbolism of a religious bestiary points to important spiritual and cosmic principles, for example strength(the bull, horse, or crocodile), abundance(the rat), evil and cunning (the snake), or innocence (the lamb, or sheep).The theophanic symbol of God's descent among people (Holy Spirit) is also marked by animal imagery (the

4 Also compare Cerberus, the three-headed dog of Greek mythology, which guarded the entrance to the underworld, Hades, where Thanatos (master of death) ruled.

5Accordingly, animal symbolism is recognized in all kinds of artistic expressions, visual and literary. Artistic expression is often closely related to religious symbolism. dove). Some of the animals in biblical and religious bestiaries are domesticated; others are wild beasts. Some of them are sinister(the snake), while others are repulsive (the rat). However, in Japanese religious traditions, the rat is a symbol of wellbeing and wealth.

Among the nations of biblical times,specific animals are often identified with deities. The religion of Ancient Egypt was based on a wide bestiary of metamorphoses and emanations. The cow Ahet was a divine herald who prepared the way for the god Ra (often depicted with a falcon's head), according to the decrees of the twin lion gods. The crocodilewas an emanation of the god Ani, whose centre of worship was inSekhem (see Budge, 1960:529-530). ${ }^{6}$

The Philistine deity Dagon was depicted ashalf fish and half man. Dagon had a human body with arms and legs, but also had a fish tail (see Judg 16:23, 1Sam 6; cf. Gray, 1962:756). The Philistines worshipped several other deities, some of whom were depicted as rats.

Animals have an important place in Bible, some appear frequently. and their role is essential for abetter understanding of the whole biblical message, Jewish and Christian.How could we understand Christianity without theLamb of God (John 1:29) or Lion from the Tribe of Judah' (Rev 5:5)? On the other hand, there are animals which occupy a contrasting, despised position, like the dog. While some animals symbolise wealth, others have extremely negative connotations, and mysteriously, some seem to have been overlooked. The cat, for example,is mentioned only once, almost as an afterthought, in the book of Baruch. Baruch was a student of the prophet Jeremiah. In an extremely vivid description of the futility and powerlessness of pagan deities and their temples, Baruch confronts idolatry thus;

The termites creep out of the ground and eat them and their clothes too, and they feel nothing. Their faces are blackened by the smoke that rises from the temple. Bats, swallows, birds of every kind perch on their bodies and heads, and so do cats (Baruch 6:19-21)

Since the cat occupied a very high position in the Egyptian pantheon, it was excluded from Jewish texts, and its absence is due to practical,religious-historical reasons. The Egyptian god Anubis had a canine head, and this may be one reason why dogs in the Bible are never mentioned in a good light. Pigs were unclean, both ritually and as food (Lev 11:7), but dogs were the embodiment of gluttony, scavengers sent by God to tear and devour. There is a graphic description of the fate of Jezebel, King Ahab'swicked wife. When Jehu saw her at the palace window he ordered,

Throw her down!'So they threw her down, and some of her blood spattered the wall and the horses as they trampled her underfoot. ... "Take care of that cursed woman," he said, "and bury her, for she was a king's

6 In Vedic religious traditions, the black cow (huan pin) represents the female principle connecting between heaven and earth. 
daughter." But when they went out to bury her, they found nothing except her skull, her feet and her hands. They went back and told Jehu, who said, "This is the word of the LORD that he spoke through his servant Elijah the Tishbite: On the plot of ground at Jezreel dogs will devour Jezebel's flesh (2 Kings 9:33-36).

The prophet Jeremiah announced great troubles ahead for the hard, unfaithful people of Israel. God would unleash four evils upon them;

I will send four kinds of destroyers against them," declares the LORD, "the sword to kill and the dogs to drag away and the birds and the wild animals to devour and destroy. (Jer $15: 3)^{7}$

Pigs and dogs are dirty and useless. Nothing valuable should be given to them.

"Do not give dogs what is sacred; do not throw your pearls to pigs. If you do, they may trample them under their feet, and turn and tear you to pieces." (Mt 7:6)

\section{Dogs and Zoolatry}

In the entire corpus of religious and historical mythology, dogs occupy central positions as guides for the souls of those who have died). In the Dictionary of Symbolsthere is an introductory overview with detailed descriptions of this canine role (cf. Chevalier, J. and Gheerbrant, A., 1987: 476480).

Anubis, or Anpu, was an Egyptian deity with a human body and canine head, sometimes simply presented as a dog. As the son of Osiris $(R a)$, his main task was to find his father's dead body (see Budge, 182). In most mythological worlds, the dog is given the task of guiding the dead. ${ }^{8} \mathrm{He}$ is closely associated with the moon and occult lunar deities (dogs howl at the full moon) (cf. Chevalier \& Gheerbrant, 1987: 476-480).

Although in the Old Testament the dog does not have a mythological position or task, it is still associated with death, and is sometimes even the instrument of God's punishment (cf. Jer 15:3), as it tears and devours corpses.

Some people consider the story of Cain and Abel as the first occasion where the $\operatorname{dog}$ is mentioned in the Bible (as anevilspirit).

Then the LORD said to Cain, 'Why are you angry? Why is your face downcast? If you do what is right, will you not be accepted? But if you do not do what is right, sin is a demon crouching (חטאת רבץ) at your door; it desires to

7 See also2Ki 9:36 and Is 56:11

8Psychopomps (Greek $\psi v \chi 0 \pi о \mu \pi$ ó $\varsigma$ ), literally "guide of souls",are angels, gods, or demi-gods, who are given the task of guide the souls of dead into the afterlife. In different cultures and religions, these guides are mainly depicted as animals (horses, ravens, dogs, owls, etc.). In Greek mythology, the task is assigned to the god Hermes. have you, but you must rule over it' (Gen 4:6-7). ${ }^{9}$

This 'demon at the door' in Hebrew is a participle of the verb (רבץ) (= to lurk, to lay in wait). ${ }^{10}$ In othertranslations it is simply the 'beast at the door'. Within the religioushistorical context already described, it may be assumed that the demon is in the form of a dog, waiting to take the victim to the afterlife. If this assumption is correct, this verse is the first allusion in the Bible to the mythological context of the ancient world.

\section{Dog, Pooch or Cur}

Dysphemism and euphemism. A euphemism makes something sound nicer than it is, or replaces certain verbaltaboos (unpleasantries or vulgarities). On the opposite side of the spectrum, there is dysphemismas intentionally pejorative and offensive. For example, the neutral word'dog' can be softened to 'pooch' or hardened to 'cur'.

In biblical Hebrew, euphemisms and dysphemisms are not grammatical forms, but are present in syntax and style.The mighty Philistine Goliath provokes David with, "Am I a dog, so you come at me with sticks?" (1 Sam 17:43).Very easily in this text the 'regular' dog (כלב) can be rendered as 'cur' (cf. 2 Sam 16:9).

The only canine euphemism (as the diminutive: 'puppy') is found in thestory of the Canaanite woman who pleaded with Jesus to share his blessing and grace with Gentiles too. She compared herself and her people to puppies (kuna, rion) waiting for scraps under the table (cf. Mt 15:27) (see: Berkovic, 2012: 219-220). In lexical terms this is much simpler as in the New Testament, the Greek lexicon recognizes diminutives, which is by no means common in Biblical Hebrew.

\section{Instead of aConclusion}

Religious and mythological bestiaries treat dogs mainly as the objects of zoolatry. Dogs also have a specific role as guides between the worlds of the living and the dead in most mythologies. In this sense, dogs are close to demons. In the biblical context, dogs are not direct spirit guides, but are perceived as scavengers and the enemies of the faithful, especially in the Psalter, where groups of dogs (enemies) threaten the psalmist's life: "Dogs surround me, a pack of villains encircles me; they pierce my hands and my feet." (Ps22:17).

Dogs as pets are not found in the Bible, and there are only rare examples of dogs being potentially useful to people (cf. Job 30:1). Dogs are treated as extremely unclean animals and personifications of dirt, filthy habits, and returning to their

9 Compare to "a demon lurking at the door" (NAB).

$10 \mathrm{In}$ the Bible, this verb is used exclusively to describe a lion lying in wait. Compare to, "You are a lion's cub, Judah; you return from the prey, my son. Like a lion he crouches and lies down, like a lioness - who dares to rouse him?" (Genesis 49:9). In Mesopotamia, the term dog was also applied to hyenas, wolves and jackals, and sometimes lions (see Black\&Green, 1998,70). 
vomit (Prov 26:11; 2Pt 2:22). Metaphorically speaking, the dog signifies worthlessness and offence. Abner is offended by Ish-Bosheth, “Am I a dog's head - on Judah's side? This very day I am loyal to the house of your father Saul and to his family and friends."(2 Sam 3:8). This particular discourse makes a pejorative comparison between people and dogs. All this is very different from the contemporary perception of the dog as 'man's best friend' and possibly the most popular pet today.

\section{References}

[1] Berković, Danijel (2012). Bestijarij u Psalmima Vrhovčeve kajkavske Biblije (eng. Bestiaries in the Psalm's of Vrhovac's Kajkavian Bible). Kairos, Evanđeoski teološki časopis, 6/2,

[2] Black, J. and Green, A. (1998). Gods, demons and symbols of ancient Mesopotamia (BritM, London)

[3] Bockmuehl, M. (1997). The Epistle to the Philippians (A\&C Black, London)

[4] Botterweck, G.J. (1980). Zebh (in TDOT, Eerdmans, Grand Rapids)

[5] Brnčić, J. (2007). Životinje u Bibliji i biblijskoj duhovnosti (u Kulturni bestijarij) (eng. Animals in the Bible and biblical spirituality (in Cultural Bestiary))

[6] Budge, E.W. (ed.) (1960). The Book of the Dead (Gramercy Books, NY) (orig.1895)

[7] Chevalier, J. and Gheerbrant, A. (1987). Rječnik Simbola (Dictionary of Symbols) (NZ MH, Zagreb)
[8] Gray, J. (1962). Dagon (in Interpreter's Dictionary of the Bible, vol.1, Abingdon Press)

[9] Marjanić, S. and Kiš, A. (2007). Kulturni bestijarij (eng. Cultural Bestiary) (HSN, Zagreb)

[10] McCullough, W. (1962). Dog (Interpreter's Dictionary of the Bible; Abingdon Press)

[11] Peterlin, D. (1995). Paul's letter to the Philippians in the light of disunity. (Brill, Leiden)

[12] Rad, G.von (1972). Genesis (SCM, London)

[13] Schwab, G. (1985). Najljepše priče klasične starine I-III(eng. The Best Stories of the Ancient Classics) (GZH, Zagreb)

[14] Simeon, R. (1969). Enciklopedijskirječniklingvisitičkihnaziva (eng.Encyclopaedic Dictionary of Linguistic Terms) (MH, Zagreb)

[15] Skok, P. (1972). Etimologijski rječnik hrvatskoga ili srpskoga jezika(eng. Etymological Dictionary of the Croatian and Serbian languages)(JAZU, Zagreb)

[16] Swanson, D.C. (1958). Diminutives in the Greek New Testament (JBL 77/2)

[17] Watt, J.M. (2013). Diminutive Suffixes in the Greek New Testament (BAGL 2)

[18] Wenham, G. (1987). Genesis-15 (Word Books, Waco)

[19] Whitekettle, R. (2001). Rats are like snakes, and hares are like goats... (Biblica82) 